\title{
The Inter-Generation of the Bosnian War in Pictures
}

\author{
Katelyn E. Giovannucci
}

\begin{abstract}
The Bosnian War allows for a fascinating glimpse into trans and intergenerational studies. The rape victims (and other war victims) themselves are first generation while the children born during the war, either as a product of rape or not, are caught in a poorly defined category as they are not simply a second generation born after the war. They were born during it and bear metaphorical wounds from it. Regardless of their biological lineage, the children of Bosnia are coming into a broken world. This 'generation' of warborn babies can to a great degree fit into Susan Suleiman's description of the $\mathbf{1 . 5}$ generation. However, it does so only loosely. Photographer Ziyah Gafić calls the children "Generation Zero." By presenting the lives of these young men and women through photographs, Gafić gives his viewers a chance to see for themselves and empathize with the stories he is trying to tell. Several noted photography theorists, including Marianne Hirsch, Susan Sontag, and W. J. T. Mitchell shed light on how photography can be so influential.
\end{abstract}

Index Terms-Bosnian war, ziyah gafic, 1.5 generation, photography, generation zero.

\section{INTRODUCTION}

Looking through the lens of Susan Rubin Suleiman, one might say that children born during the Bosnian War are members of the 1.5 generation, "child survivors...too young to have an adult understanding of what was happening to them, but old enough to have been there..." [1]. Children who were either born during or immediately following the war, are at the level of least comprehension. They were there, but have no recollection of what happened during the war. Suleiman focuses only on the Holocaust; she doesn't extend her theory to include other victims of tragedy. She argues that the experiences of the 1.5 generation are so different "that the idea of a 1.5 generation... is a lost cause - or, to be less drastic about it, an idea with very limited usefulness" [1]. The experiences of each person varies so much from another that drawing a hard and fast line around those who can be deemed to represent a particular generation seems nearly impossible. Perhaps, though, Suleiman narrowed her scope too far.

\section{PhOTOGRAPHY AND EMPATHY}

Suleiman argues that an all-encompassing term like 1.5 generation does not cover all facets of testimony and experience. She does not want to abandon the notion altogether, but rather advocates for an even broader notion of the 1.5 generation: "I want to propose that is as personal,

Manuscript received April 11, 2013; revised June 24, 2013.

Katelyn E. Giovannucci is with the Salem State University, USA (email: Katelyn@alum.mit.edu). subjective expression that the experiences of children in the Holocaust can most memorably be communicated. Ultimately, the meaning of their experience remains, despite the collective nature of the historical event and of its official commemorations, individual rather than collective..." [1]. If one follows this particular idea of generations then one might logically assume that there is no such thing as a defined generation as the experiences of people within a generation varies widely and cannot be grouped collectively. Suleiman herself acknowledges that there will be differences in testimony and experience based on location, etc. even within the survivors of the Holocaust. The children of the Holocaust may have differing experiences, but that does not necessarily preclude them from the title of a generation.

Perhaps what needs to be examined is how one perceives a generation. Suleiman ponders this generation with the intent of finding a collective thread, a tactic that does not seem to work for the Holocaust, nor for the Bosnian War. The structure, presentation, and experiences are all different, but one characteristic does unite them. Suleiman's initial intent of finding a generation connection may lie instead in acknowledging that the experiences simply share the thread of common experience, but that the personal ramifications of the conflict differ, thus enriching, rather than negating the generation.

Child survivors of the Bosnian War comprise a lost generation, a generation that Bosnian photographer Ziyah Gafić captures the sorrow, despair, yet tragic hope of in Generation Zero. These pictures are a portal connecting the children with a larger, world audience, attempting to foster a sense of empathy for them. Gafic was born and raised in the capital city of Sarajevo and was a teenager during most of the Bosnian war. In Generation Zero, Gafic tells the stories of dozens of teenagers, all born during the Bosnian War, and offers his audience the opportunity to see Bosnia's 1.5 generation and attempt to establish an emotional connection with their experiences.

Photographs are a powerful way to capture moments in time and invite an audience to witness that moment as well. The power of photography has been discussed since its invention while the power of image has been investigated for centuries. Theory on how to approach photo analysis has developed over time with several scholars leading the way. Marianne Hirsch, Susan Sontag, and W. J. T. Mitchell have contributed significantly to the field of photography theory.

Marianne Hirsch, in her book Family Frames: Photography Narrative and Postmemory, writes about family photos and versions of family photos and discusses how examining them is like looking at history. Susan Sontag also addresses the role of photography is preserving history, but she emphasizes its role in capturing beauty. In her book On Photography, a collection of essays exploring 
the amorphous nature of photography, published in 1997 , Sontag addresses basic concepts of photography analysis. W. J. T. Mitchell believes in the beauty of photography, but rather than look at pictures from the outside, he looks at them from the inside. The title of his book is suggestive in and of itself. He poses the question What Do Pictures Want? Rather than an audience looking at a picture, Mitchell proposes a picture take in the audience.

Hirsch, Sontag, and Mitchell propound ways to think about the power of photography. At its basest level, photography is a lens through which people can connect, the tool that people use to capture a memory, preserve history, and mark beauty. Pictures beg to be looked at, examined, considered as entities and as such, invite viewers to consider what is happening in them and why. Gafić's Generation Zero pictures ask the audience to look into the lives of the children born during the war, to try to establish a relationship with them through photography.

In his collection, Generation Zero, Gafić offers his audience the opportunity to see the children born during the war as they are growing up. Through this, the 'reader,' as Gafić sometimes refers to his audience, can open his or her mind to try to understand the experiences of these children. His description of the collection is brief, but powerful: "Teenagers of Bosnia. All born during the war, without any guilt or memories. Born without knowing that someone has already stolen their future" [5]. The 12 photos each present a story that is reminiscent of hundreds of other children living the same sad life. Gafić does not specify that they are the product of rape; the war has lasting effects on everyone alive during or born during the war. They are in between kids and adults, making the children in his collection not quite children anymore. They are starting to figure out the world, their world, and their place in it. The pictures show the children in their natural state, living their lives. They are just like other teenagers and nothing like other teenagers because they are the children of the Bosnian War.

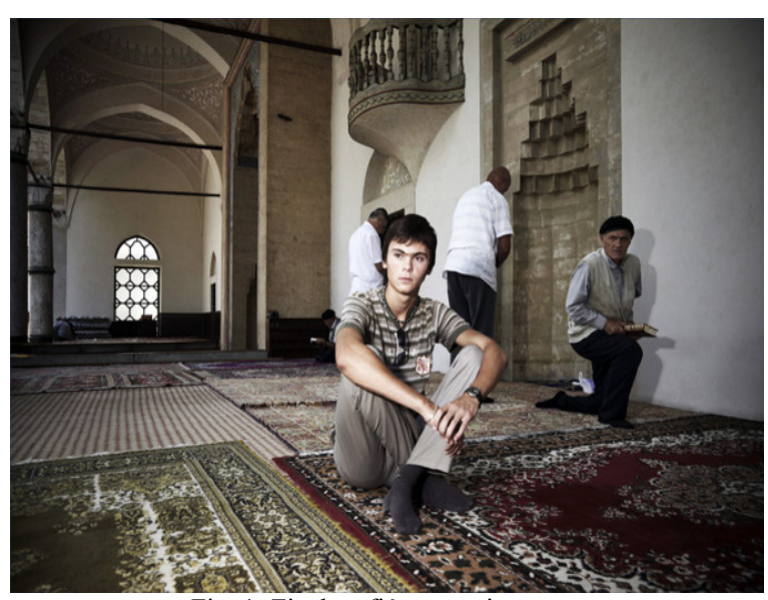

Fig. 1. Ziyah gafić generation zero.

Fig. 1 in Gafić's collection consists of a young man in a religious building. The separation between young and old as well as indicating a division in religious adherence that forever marks the evolution of youth dominates this picture. Sontag encourages audiences to take in everything about a picture as it is a permanent structure of both beauty and history: "But not withstanding the declared aims of indiscreet, unposed, often harsh photography to reveal truth, not beauty, photography still beautifies" [3]. There is something hauntingly beautiful about the setup and juxtaposition of people in this picture. There are five men, and no women in this picture. All but the young man in the picture's focus are older and involved in some sort of prayer. The setting presents indications that this is a Muslim mosque: the floors are lined with rugs for praying, the walls have prayer enclaves, and there are ornately designed window frames- the building itself seems very impressive. The picture captures the aftermath of the war, preserving the history of the 1.5 generation, one that questions and begs answers to things that may remain unknown. These children were not alive before or during the war; they only know life after it. They had no choice in when and where they were born, but live the war every day of their lives without knowing why or how to stop it, but more tragically, the reality is that he cannot stop it.

The young man in the foreground of the picture has a story to tell. Mitchell asks us to allow the story to tell it by giving the picture a chance to ask the questions or to at least elicit them: "I'd like to shift the location of desire to images themselves, and ask what pictures want" [4]. The picture is allowed to tell its own story, and in doing this, the possibilities for photography analysis are endless. By allowing the focus to be on the pictures needs, the picture then tells the viewer what questions to ask. The number of questions one could ask is limitless and pondering the answers is an effective way of connecting to the subject of the pictures. Why is the young man seated away from the other praying men? He seems to be going through the motions of praying properly as he has removed his shoes and is seated on the floor, but he is not actively praying. His eyes are looking off into the distance, not into the camera. It is almost as if he is not mindful of the camera's presence at all. What is he thinking, or not thinking as the case may be? His face does not appear to show anger, but rather disillusionment as if he had hoped to find something in this place that he never found.

Mitchell's questioning technique can be applied to the background of the picture as well. Fully understanding pictures is a two way process, what we ask the picture and what the picture asks us: "The question to as of pictures from the standpoint of a poetics is not just what they mean or do, but what they want - what claim they make upon us, and how we are to respond" [4]. Gafić's picture wants us to probe into what is happening behind the young man. The men behind him provide a stark contrast to him. They are all actively praying, standing, sitting, or kneeling near a wall. One man is on one knee. He is looking in the direction of the camera, asking the photographer to take note of the scene. He wears a traditional cap and holds a book in his hand. Two other men are standing, cap-less heads bent down in prayer. They are facing the wall, not at all cognizant of the camera's presence. The last man is seated cross-legged on the floor, also in prayer, and equally unmindful of the camera. What purpose does each individual man have in this picture? Do they have a connection to the young man? What are their war stories? The young man, in his physical, and apparently emotional, separation seems to express an unhappiness with life that is very telling of Bosnia's 1.5 generation, the generation living 
out a brand new war story.

Bosnian war children are caught between two lives- the traditional life led by their ancestors, a life troubled with ethnic and religious quarrels, and a new life, attempting to be enjoyed by those who have moved on from the war or came after the war. Gafic shows the world the 1.5, tangled generation - they are caught between a violent past and an uncertain future. They do not know their place because they do not have one. The young man sitting in the foreground of this photograph has a blank stare that is a combination of sadness, hopelessness, confusion, and anger. He does not belong to the Bosnia of old. That Bosnia does not want him. He cannot have the new Bosnia. That Bosnia does not seem to acknowledge him because it is still a country in flux, not having made much forward progress socially or economically. Thus, he and all of the other children born during the war, remain stagnant, their lives not their own.

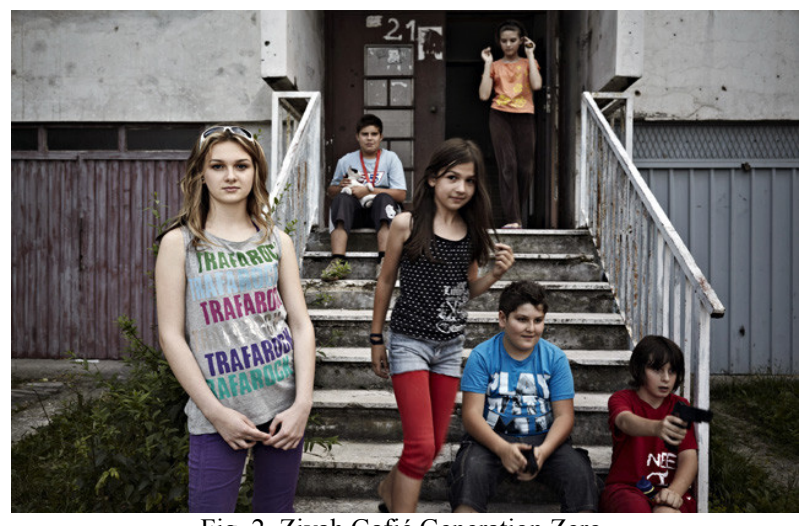

Fig. 2. Ziyah Gafić Generation Zero.

Another Gafić photograph (See Fig. 2) that is relevant to a discussion about the Bosnian 1.5 generation because of its ability to capture the simplicity of childhood juxtaposed with the pain of the aftermath of war. The picture shows a group of children sitting on some steps in a modern day Bosnian neighborhood, welcoming the viewer into the family of Bosnia's 1.5 generation. Like the pictures mentioned before, these children are somehow out of place in modern Bosnia. This picture captures Sontag's ideas about beauty and history and once again shows how they are interwoven. According to Sontag, "beauty has been revealed by photographs as existing everywhere... For photographers there is... no difference - no greater aesthetic advantage-between the effort to embellish the world and the counter-effort to rip off its mask" [3]. In other words, whether the photographer seeks to create beauty in a picture or reveal the story beneath a picture, the photographs are beautiful. Gafić's picture itself is rather stark with grey tones and children sitting in front of a rundown building, showing no intention of forcing beauty, but rather showing reality. Yet there is beauty in the somber dullness of the picture, a quietness that invites the audience into the world of the children. Gafić's picture communicates so much through the faces and actions of these six children who are going about their daily lives. The home they are crowding near the entrance of is rundown- exterior is dirty and the concrete walls appear to be cracking. The stairs themselves are rickety and worn down and look as though they could collapse. The front door is worn and anything but welcoming. The physical home of these children is symbolic of the lives they lead- broken, worn down even though they are still quite young.

The picture asks the viewer to pose questions to it, or so Mitchell would argue. Mitchell contends that pictures have a vital quality to them: "Pictures are things that have been marked with all the stigmata of personhood and animation: they exhibit both physical and virtual bodies; they speak to us, sometimes literally, sometimes figuratively" [4]. Photographs have a very interactive quality that begs viewers to listen to them. By allowing the picture to dictate the questions, the answers to them help the audience to better understand, communicate with, and empathize with the subjects. They are the children of the war and victims of the aftermath of trauma whose power is not their own. Why do their eyes suggest knowledge they should not possess?

By looking specifically at the children in the foreground and applying Mitchell's concept of allowing the picture to speak and provide the questions, the photograph invites even more discussion about trauma. The two girls, standing, are dressed in brighter clothes and their expression is quixotic. They have a look in their eyes that suggests that they know more about life than the audience will ever know. What do they know? What have they seen? What have they not seen that makes them who they are today? They appear wise beyond their years. They know a type of sadness and suffering children should never know; yet they bear it with an air of confidence and resolve. The two boys sitting on the steps in the foreground are the most alarming. One boy, dressed in red, holds a gun and points it toward something off-camera. The other boy watches, evidently entertained by the gun pointing. What or who is he pointing at? The gun is a tragic reminder the war that bred these young men and women. They did not experience the violence firsthand, but they live the results of the violence every day of their lives.

In this single picture, Gafić shows youthful ignorance and advanced maturity. The Bosnian War created a multitude of problems that cannot be fixed immediately, problems that will likely take several generations to work through fully. Unfortunately for these children, they cannot partake in a normal life. They were not born under normal circumstances. By seeing the physical situation and expressions of hopeful despair, Gafić's readers are able to more closely identify with those suffering the consequences of war. The war did not affect a single generation; in fact, its ramifications could continue for many generations ahead. The children pictured in Generation Zero did not directly experience the war. They were born during it, but do not remember living through it, yet the trauma of it touches their daily lives. Trauma does not end with the generation it directly victimizes, it continues and lays a dark shadow of the history of those coming after it.

Hirsch believes that the camera lens is a universal communicator because it is through the lens that the pieces of history can come together to form a conglomerated history: "I trace the intersection of private and public history...Photographs offer a prism through which to study the postmodern space of cultural memory composed of leftovers, debris, single items that are left to be collected and assembled in many ways, to tell various stories, from a variety of often competing perspectives" [2]. Individually, 
the pictures may not necessarily hold much power, but together, they unite people to tell a story, a history even of the world.

\section{CONCLUSION}

Suleiman argues that one cannot put a definite label on a 1.5 generation because their experiences are too different. The children of the Bosnian War, by nature of the fact that they exist, refute that. Granted, some express more hope, and occasionally some will be granted more opportunities than others, but by and large, they have the same discontentment and longing for something better, something denied to them by the actions of their ancestors. The trauma did not happen to them, but they cannot escape it. Gafić's photographs are an artistic representation of the aftermath of trauma. The seemingly normal lives of the children are infinitely relatable, but the overwhelming sadness that is inherent in the pictures may not be. Trauma art, in the form of Zero Generation, gives audiences a chance to see what has come from and after the Bosnian War, to provide a chance to extend compassion to the children whose futures have been taken from them.

\section{REFERENCES}

[1] S. R. Suleiman, "The 1.5 Generation: Thinking about child Survivors and the holocaust," American Imago, vol. 59, no. 3, pp. 277-295, 2002.

[2] M. Hirsch, Family Frames: Photography, Narrative, and Postmemory, Cambridge: Harvard University Press, 1997.

[3] S. Sontag, On Photography, New York: Dell Publishing, 1977.

[4] W. J. T. Mitchell, What Do Pictures Want? Chicago: University of Chicago Press, 2005.

[5] Z. Gafić. (2009). Generation Zero. Ziyah Gafić, Photographer. [Online]. Available: http://www.ziyahgafic.ba/photo.php?id=16

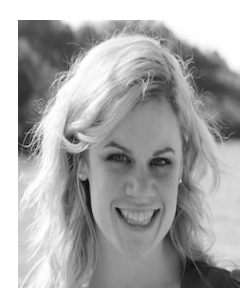

Katelyn E. Giovannucci was born in Falmouth, Massachusetts, United States on May 30, 1985. Miss Giovannucci graduated from the Massachusetts Institute of Technology (Cambridge, MA, USA) with a Bachelor of Science degree in Linguistics and Philosophy in 2007. Miss Giovannucci graduated from Salem State University (Salem, MA, USA) with a Master of Arts degree in English in 2013.

She is currently an English teacher at Danvers High School (Danvers, MA, USA). She formerly taught at Newton North High School (Newton, MA, USA). She is currently researching trauma art, specifically as pertains to Bosnia. She hopes to continue these pursuits. 